\title{
The Roles of Rab27 and Its Effectors in the Regulated Secretory Pathways
}

\author{
Tetsuro Izumi*, Hiroshi Gomi, Kazuo Kasai, Shin Mizutani, and Seiji Torii \\ Department of Molecular Medicine, Institute for Molecular and Cellular Regulation, Gunma University, \\ Maebashi 371-8512, Japan
}

\begin{abstract}
Regulated secretory pathways are highly developed in multicellular organisms as a means of intercellular communication. Each of these pathways harbors unique store organelles, such as granules in endocrine and exocrine tissues and melanosomes in melanocytes. It has recently been shown that the monomeric GTPase Rab27 subfamily regulates the exocytosis of these cell-specific store organelles. Furthermore, genetic alterations of Rab27a cause Griscelli syndrome in humans that manifests as pigmentary dilution of the skin and the hair and variable immunodeficiency due to defects in the transport of melanosomes in melanocytes and lytic granules in cytotoxic T-lymphocytes. Rab27 acts through organelle-specific effector proteins, such as granuphilin in pancreatic beta cells and melanophilin in melanocytes. The Rab27 and effector complex then interacts with proteins that are essential for membrane transport and fusion, such as syntaxin 1a and Munc18-1 for granuphilin and myosin Va for melanophilin. Genome information suggests that other putative Rab27 effector proteins, tentatively termed as exophilins or Slp/Slac2, are predicted to exist because these proteins share the conserved $\mathrm{N}$ terminal Rab27-binding domain and show Rab27-binding activity in vitro or when overexpressed in cell lines. These findings suggest that the Rab27 subfamily regulates various exocytotic pathways using multiple organellespecific effector proteins.
\end{abstract}

Key words: regulated secretion/Rab27/granuphilin/melanophilin/secretory granule/lysosome-related organelle

\section{Regulated secretory pathways}

Secretion of bioactive substances is a means of intercellular communication by which multicellular organisms coordinate the activities of their constituent cells and thereby function as an integrated unit. The secretory pathways can be divided into two types: constitutive and regulated secretion (Burgess and Kelly, 1987). In the constitutive secretory pathway, proteins are continuously secreted depending on the amount synthesized. The transcription and translation steps are the limiting steps in this type of pathway, and these take at least several hours. By contrast, in the regulated secretory pathway, synthesized products are first stored in organelles and released only when cells are stimulated by an appropriate extracellular secretagogue. The secretagogue in

*To whom correspondence should be addressed: Tetsuro Izumi, Department of Molecular Medicine, Institute for Molecular and Cellular Regulation, Gunma University, 3-39-15 Showa-machi, Maebashi, Gunma 371-8512, Japan.

Tel: +81-27-220-8856, Fax: +81-27-220-8860

E-mail: tizumi@showa.gunma-u.ac.jp.

Abbreviations: SM, Sec1/Munc18; SNARE, soluble $N$-ethylmaleimidesensitive factor attachment protein receptor. turn changes the level of an intracellular second messenger, such as $\mathrm{Ca}^{2+}$. Differentiation of store organelles in this pathway enables rapid and quantitative intercellular communications. In neuronal cells, synaptic vesicles mediate membrane fusion in periods as short as $60 \mu \mathrm{s}$ after $\mathrm{Ca}^{2+}$ entry (Sabatini and Regehr, 1996), and undergo extensive exocytic-endocytic recycling. Granules in endocrine and exocrine cells, however, show longer latencies $(5-100 \mathrm{~ms})$ between $\mathrm{Ca}^{2+}$ entry and membrane fusion (Chow et al., 1992), but secrete a larger amount of hormones or enzymes that will be diluted out in circulation or digestive tracts. Other lysosome-related organelles, such as melanosomes containing the pigment melanin, are translocated and secreted by poorly characterized mechanisms; three modes of melanosome transfer from melanocytes to adjacent keratinocytes have thus far been proposed (Marks and Seabra, 2001). Thus, each store organelle is exocytosed at a distinct speed and kinetics in accordance with the biological function of the secretory products. Although the basic machinery for vesicle transport is believed to be conserved from yeast to humans and in all intracellular pathways, the regulated secretory pathways should be endowed with additional components. These include a constraint that prevents spon- 
taneous secretion in the absence of a secretagogue, a sensor that detects the arrival of secretagogue-dependent signals such as an increase in intracellular $\mathrm{Ca}^{2+}$, and a modifier that amplifies or reduces the efficiency of exocytotic events. In fact, biochemical studies have identified numbers of proteins that associate with the store organelle and release site, and that finely tune each pathway, as in the case of synaptic vesicles (Südhof, 1995) and presynaptic active zones (Garner et al., 2000). Genetic approaches have also uncovered the genes whose mutations specifically affect the transport of melanosomes and other related organelles in several monogenic diseases (Marks and Seabra, 2001).

The present study reviewed recent progress in the understanding of the roles of Rab27 and its effector proteins in the regulated secretory pathways. Rab proteins are monomeric GTPases of the Ras superfamily and regulate various transport pathways of intracellular vesicles. Many Rab proteins have been described to show specific patterns of subcellular localization and tissue distribution. The number of RAB genes is expanded to 60 in humans compared with 11 corresponding Ypt genes in budding yeast $S$. cerevisiae (Bock et al., 2001). Robust expansion of Rab proteins in higher eukaryotes reflects the increased complexity and variability of intracellular compartments, particularly the uniquely differentiated store organelles in the regulated secretory pathways. Until recently, however, Rab3 was the only Rab subfamily to be investigated in the regulated secretory pathways, although its exact role remains enigmatic (Jahn and Südhof, 1999) (see later discussion). The Rab27 subfamily, which consists of Rab27a and b, has recently been studied extensively, and despite its relatively short history of investigation, it has been demonstrated to function in several regulated secretory pathways.

\section{Rab27 and lysosome-related organelles}

The epoch-making study of Rab27 was the result of a discovery that mutations of the $R A B 27 A$ gene cause Griscelli syndrome in humans (Ménasché et al., 2000). Rab27 is the first example of a Rab specifically implicated in a human genetic disease (Table I). Griscelli syndrome, a rare autosomal recessive disorder, results in pigmentary dilution of the skin and the hair and variable immunodeficiency. It is characterized by the presence of large clumps of pigment in hair shafts and the accumulation of mature melanosomes in melanocytes with reduced pigmentation of adjacent keratinocytes, and is accompanied by an uncontrolled activity of the T-lymphocytes and macrophages triggered by infections known as haemophagocytotic syndrome (Kleine et al., 1994). A mutation of the mouse ortholog Rab27a is responsible for a lightened coat color in ashen mice (Wilson et al., 2000). Subsequent analyses demonstrated that Rab27a is

Table I. Phenotypes DUe to RAB MUtATION AND DELETION IN VIVO

\begin{tabular}{|c|c|c|c|c|c|}
\hline $\mathrm{Rab}$ & Expression & $\begin{array}{l}\text { Human disease } \\
\text { Mouse mutant }\end{array}$ & Phenotypes & Function & References \\
\hline \multirow[t]{2}{*}{ Rab3a } & $\begin{array}{l}\text { Nerve cells } \\
\text { Endocrine cells }\end{array}$ & Rab3a knockout & $\begin{array}{l}\text { More exocytotic events, an } \\
\text { enhanced rundown, and lack } \\
\text { of LTP (hippocampal mossy } \\
\text { fibre synapses) } \\
\text { Decreased secretagogue- } \\
\text { induced insulin release }\end{array}$ & Inhibition of fusion? & $\begin{array}{l}\text { Geppert et al., 1994, } 1997 \\
\text { Castillo et al., } 1997 \\
\text { Lonart et al., } 1998 \\
\text { Kapfhamer et al., } 2002 \\
\text { Yaekura et al., } 2003\end{array}$ \\
\hline & & earlybird (Rab3a D77G) & $\begin{array}{l}\text { Shortened circadian period } \\
\text { of locomotor activity }\end{array}$ & $\begin{array}{l}\text { Circadian period and sleep } \\
\text { homeostasis }\end{array}$ & \\
\hline Rab3d & $\begin{array}{l}\text { Mast cells } \\
\text { Exocrine cells } \\
\text { Adipocytes }\end{array}$ & Rab3d knockout & $\begin{array}{l}\text { Increased size of granules } \\
\text { Normal secretion }\end{array}$ & $\begin{array}{l}\text { Granule maturation } \\
\text { (preventing homotypic } \\
\text { fusion?) }\end{array}$ & Riedel et al., 2002 \\
\hline Rab7 & Ubiquitous & $\begin{array}{l}\text { Charcot-Marie-Tooth } \\
\text { type 2B (CMT2B) } \\
\text { neuropathy }\end{array}$ & $\begin{array}{l}\text { Ulceromutilating neuropathies } \\
\text { (muscle weakness, foot ulcers } \\
\text { and infection) }\end{array}$ & $\begin{array}{l}\text { Transport between late } \\
\text { endosomes and lysosomes } \\
\text { (late endocytotic transport) }\end{array}$ & Verhoeven et al., 2003 \\
\hline Rab23 & Nerve cells & open brain (opb) & $\begin{array}{l}\text { Embryonic lethal } \\
\text { Open neural tubes } \\
\text { (head and spinal cord) }\end{array}$ & $\begin{array}{l}\text { Neural patterning } \\
\text { (translocation of vesicles } \\
\text { to the plasma membrane?) }\end{array}$ & $\begin{array}{l}\text { Eggenschwiler et al., } \\
2001\end{array}$ \\
\hline $\mathrm{Rab} 27 \mathrm{a}$ & $\begin{array}{l}\text { Endocrine cells } \\
\text { Melanocytes } \\
\text { Hemopoietic cells }\end{array}$ & $\begin{array}{l}\text { Griscelli syndrome } \\
\text { (type 1) } \\
\text { ashen }(\text { ash })\end{array}$ & $\begin{array}{l}\text { Partial albinism } \\
\text { Haemophagocytic syndrome }\end{array}$ & $\begin{array}{l}\text { Movement of melanosomes } \\
\text { Cytotoxic } \mathrm{T} \text { lymphocyte } \\
\text { granule release }\end{array}$ & $\begin{array}{l}\text { Ménasché et al., } 2000 \\
\text { Wilson et al., } 2000\end{array}$ \\
\hline Rab38 & Melanocytes & chocolate (cht) & Partial albinism & $\begin{array}{l}\text { Sorting of TYRP1 (tyrosinase } \\
\text {-related protein) }\end{array}$ & Loftus et al., 2002 \\
\hline
\end{tabular}

In vivo function of Rab proteins manifested in human disease or revealed by the phenotypes of natural mutant or gene-targeted mice. Bold, name of human disease; Italics, name of natural mutant mouse. 
colocalized with melanosomes in melanocytes (Bahadoran et al., 2001; Hume et al., 2001) and lytic granules in cytotoxic T-lymphocytes (Haddad et al., 2001). In melanocytes of Griscelli patients and ashen mice, melanosomes are clumped in perinuclear regions, and reexpression of wildtype Rab27a protein restores melanosome transport to dendrite tips (Bahadoran et al., 2001; Hume et al., 2001; Wilson et al., 2000). Rab27a-deficient T-lymphocytes exhibit drastically reduced cytotoxicity and lytic granule exocytosis (Haddad et al., 2001; Ménasché et al., 2000; Stinchcombe et al., 2001). Consistently, ashen lytic granules do not reach the plasma membrane at the immunological synapse, although they are polarized to the target cell interface (Stinchcombe et al., 2001). While the presence of a bleeding tendency in ashen mice is controversial, the defect in platelet dense granules is either dependent on genetic background (Novak et al., 2002; Wilson et al., 2000) or compensated for by coexisting Rab27b (Barral et $a l ., 2002)$. These findings indicate that $\mathrm{Rab} 27 \mathrm{a}$ regulates the exocytosis of organelles generically named as secretory lysosomes (Blott and Griffiths, 2002) or lysosome-related organelles (Dell'Angelica et al., 2000). Melanosomes in melanocytes, lytic granules in T-lymphocytes, and platelet dense granules share mixed characteristics of lysosomes and secretory granules. They harbor lysosomal marker proteins, although they specifically perform exocytotic functions unrelated to degradation.

\section{Rab27 and secretory granules}

A completely different and independent approach revealed that the Rab27 subfamily also regulates the exocytosis of classical secretory granules. In 1999, a novel gene was discovered that is specifically expressed in pancreatic beta cells and pituitary tissue (Wang et al., 1999). The domain structure of the protein product named granuphilin is similar to that of rabphilin3, a Rab3 effector protein (Shirataki et al., 1993), although the overall identity of the primary sequences only amounts to $22 \%$. It was subsequently shown that granuphilin physiologically interacts with Rab27a in pancreatic beta cells, although it also has an affinity to Rab3a in vitro (Yi et al., 2002). Rab27a is localized on the membrane of insulin granules, and its overexpression enhances high $\mathrm{K}^{+}$-stimulated insulin secretion. Furthermore, Rab27b is also expressed in pituitary endocrine cells including corticotrophs and intermediate lobe cells, and the expression of the inactive mutant of Rab27b inhibits ACTH secretion from AtT20 cells (Zhao et al., 2002). These findings suggest that Rab27a and Rab27b have positive roles in the exocytosis of endocrine secretory granules, although, in contrast to the case of lysosome-related organelles, genetic evidence is lacking. In any case, we recently found that the exocytosis of endocrine granules is actually affected in ashen mice (our unpublished observations).

\section{Multiple putative Rab27 effectors}

A search of the genome using granuphilin as a prototype indicated that similar proteins probably exist. These proteins are tentatively termed as exophilins (exocytosis-associated rabphilin3/granuphilin-like proteins) (Nagashima et $a l .$, 2002) or Slp (synaptotagmin-like protein)/Slac2 (Slp homologus lacking $\underline{\mathrm{C} 2}$ domains) (Fukuda and Mikoshiba, 2001; Kuroda et al., 2002a) (Fig. 1). They share highly conserved amino acid sequences at the N-termini (Fig. 2), including the SGAWFF motif that in rabphilin3 may play a critical role in binding to Rab3a-GTP (Ostermeier and Brunger, 1999). Although these putative Rab-binding regions are often inserted by a zinc finger domain harboring a series of conserved cysteine residues, this domain is missing in exophilins 4, 5, and 7, and is shown to be dispensable for Rab binding in some exophilins (Fukuda, 2002; Nagashima et al., 2002; our unpublished observations), which suggests that it may have other roles. The zinc finger region may confer higher affinity to Rab, similar to that of rabphilin3 to Rab3a as seen in surface plasmon resonance and pull-down experiments (Wang et al., 2001).

In addition to granuphilin, another protein termed melanophilin (exophilin3, Slac2-a) has been found to function as a Rab27a effector. The gene encoding melanophilin is mutated in leaden coat-color mutant mice (Matesic et al., 2001) that are genetically correlated with ashen mice. Although all exophilins can form a complex with Rab27a or $\mathrm{Rab} 27 \mathrm{~b}$ in vitro or when overexpressed in non-secretory cells (Kuroda et al., 2002a; our unpublished observations), it should be noted that the existence of endogenous complexes has not been demonstrated in most cases. Furthermore, some of these proteins have been shown to have affinities to other Rab proteins (Kuroda et al., 2002a; Yi et $a l ., 2002)$. Thus, it remains to be clarified whether they physiologically represent Rab27 effectors, except for melanophilin and granuphilin whose physiological interactions with Rab27a have been demonstrated (see below).

In contrast to the $\mathrm{N}$-termini, the $\mathrm{C}$-termini of these proteins bear unique sequences (Fig. 1). Several have two tandem C2-domains at the C-termini. This feature is consistent with their roles in membrane traffic, because the $\mathrm{C} 2$ domain in general has affinities to phospholipids in either a $\mathrm{Ca}^{2+}$-dependent or a $\mathrm{Ca}^{2+}$-independent manner (Rizo and Südhof, 1998). Almost all of the C2 domains of exophilins, however, partly lack the aspartate, glutamate, or serine residues that are conserved and involved in $\mathrm{Ca}^{2+}$ binding in synaptotagmins and rabphilin3 (Rizo and Südhof, 1998), placing in doubt whether they actually bind $\mathrm{Ca}^{2+}$. Exophilins 3, 5, and 8 lack $\mathrm{C} 2$ domains, and exophilins 3 and 8 have been shown to interact with unconventional myosin Va and VIIa, respectively, through the predicted coiled-coil C-terminal domains (see below). The existence of multiple putative effector proteins suggests that the roles of Rab27 vary in different cells, depending on the effector protein 


\section{Exophilin2/ Granuphilin-a}

Exophilin3/ Melanophilin

\section{Exophilin4/ SIp2-a}

Exophilin5/ Slac2-b

Exophilin6/ SIp3

\section{Exophilin7/} JFC1/ SIp1

\section{Exophilin8/ MyRIP/ Slac2-c}

\section{Exophilin9/ SIp5}


1989
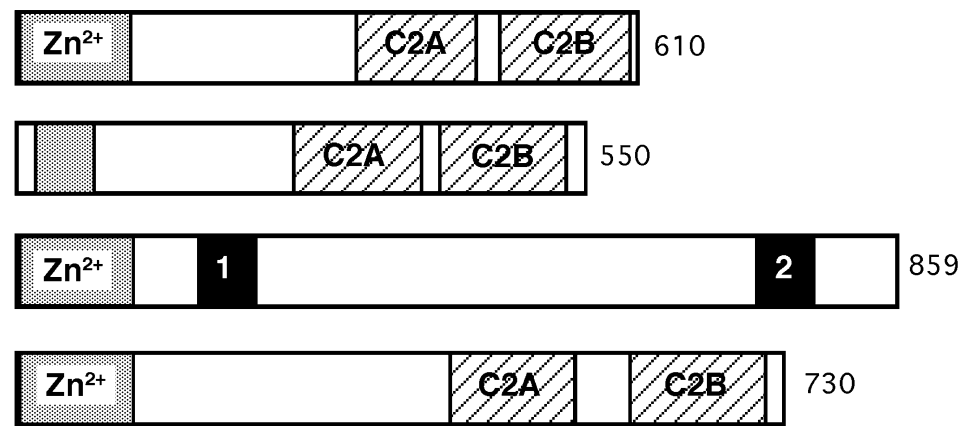

Fig. 1. Domain structures of putative Rab27 effector proteins (Modified from Nagashima et al., 2002). The domain structures of putative Rab27 effector proteins are schematically represented. The amino acid numbers shown on the right are those of human genes. Gray box, N-terminal homologous Rabbinding region; $\mathrm{Zn}^{2+}$, zinc-finger motif; dashed box, $\mathrm{C} 2$ domain; black box, coiled-coils.

employed.

\section{Granuphilin (Slp4)}

Granuphilin is the first Rab27 effector whose amino acid sequence is completely determined. It was identified by mRNA differential display as a gene that is preferentially expressed in pancreatic beta versus alpha cell lines (Wang et al., 1999). The larger isoform, granuphilin-a, has two C2 domains, whereas the smaller one, granuphilin-b, contains only the first $\mathrm{C} 2$ domain. Granuphilins have a restricted tissue distribution, being specifically expressed in pancreatic beta cells and pituitary tissue, but not in pancreatic alpha cells, the adrenal gland, or other major organs including the brain. They are localized on the membrane of insulin granules in pancreatic beta cells (Yi et al., 2002), and their overexpression is inhibitory for $\mathrm{K}^{+}$-induced insulin secretion (Coppola et al., 2002; Torii et al., 2002), although it significantly enhances basal secretion (Torii et al., 2002). Although Rab3a has an ability to interact with the N-terminal region of granuphilin in vitro and when overexpressed in cells (Coppola et al., 2002; Yi et al., 2002), Rab27a is considered a principal Rab partner of granuphilin, at least in a beta cell line MIN6, for the following reasons (Yi et al., 2002). First, endogenous Rab27a, but not Rab3a, significantly forms a complex with granuphilin. Second, Rab27a, but not Rab3a, has been shown to be cofractionated with granuphilin in an analysis of sucrose density gradient subcellular fractionation. Third, the tissue distributions of gran- uphilin and Rab27a are remarkably similar. Neither protein is expressed in brain where Rab3a is specifically and abundantly expressed. It is, however, possible that a portion of Rab3a interacts with granuphilin and is involved in a distinct exocytotic step of insulin granules because pancreatic beta cells express members of the Rab3 subfamily (Regazzi et al., 1996).

Although the mechanism of granuphilin activity in the exocytotic pathway remains unknown, it is known to directly bind to syntaxin 1a (Torii et al., 2002) and Munc181 (Coppola et al., 2002), both of which are essential for membrane fusion (Fig. 3, left). Similar interactions of Rab effectors with either syntaxins or Sec1/Munc18 (SM) proteins are found in other transport pathways, including those in yeast where there is supporting genetic evidence (Segev, 2001; Zerial and McBride, 2001). For example, a Rab5 effector EEA1 interacts with syntaxin 6 and syntaxin 13, whereas a Rab1 effector p115 forms a complex including syntaxin 5. Interactions with SM proteins are exemplified by a Ypt51 effector Vac1 or a Rab5 effector rabenosyn to Vps45 and by a Ypt7 effector complex HOPS to Vps33. These findings suggest a model in which Rab recruits an effector and then, in turn, interacts with syntaxin, a component of soluble $N$-ethylmaleimide-sensitive factor attachment protein receptors (SNARE), and/or a SM protein, which has a direct role in SNARE complex formation and in membrane fusion. Therefore, the interaction of granuphilin with syntaxin 1a and/or Munc18-1 may have an important role in the tethering and fusion of granules to plasma 


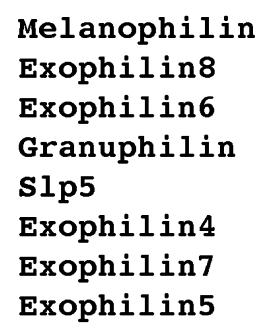

Melanophilin Exophilin8 Exophilin6 Granuphilin Slp5 Exophilin4 Exophilin 7 Exophilin5

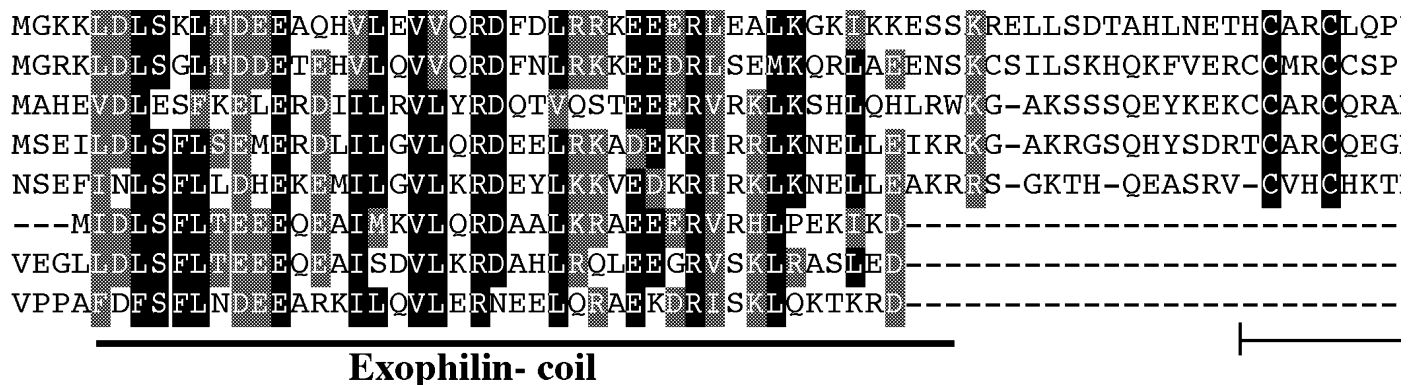

Exophilin- coil



132

132

131

130

131

65

96

64

Fig. 2. Amino acid alignments of N-terminal sequences of exophilins (Modified from Nagashima et al., 2002). The N-terminal Rab27-binding region of putative Rab27 effector proteins is aligned. The putative Rab-binding coiled-coil sequences are shown. Residues conserved in at least five members are shown in dark boxes. The sequences of granuphilin, exophilins 6-8, and Slp5 are derived from mouse genes, whereas those of melanophilin, and exophilins 4 and 5 are from human genes.

membrane.

It should be noted that most SM proteins have a high binding affinity for syntaxins, as originally found between Munc18-1 and syntaxin 1a in neurons (Hata et al., 1993). Munc18-1 shows an affinity exclusively to a closed form of syntaxin 1a that is not compatible with the SNARE assembly (Dulubova et al., 1999). This mode of interaction seems to represent a specialization in the regulated secretory pathway because in other pathways SM proteins interact with syntaxins in a way that does not prevent SNARE complex formation (Rizo and Südhof, 2002). Therefore, Munc18-1 must be dissociated from syntaxin la before membrane fusion, which may reflect the nature of the regulated secretory pathway where membrane fusion should not occur until an appropriate extracellular secretagogue arrives. Granuphilin can directly and separately bind to syntaxin 1a and Munc18-1 in vitro. Because syntaxin 1a and Munc18-1 also forms a complex, it is currently unclear whether granuphilin forms a complex with either protein simultaneously or separately in vivo. In any case, since granuphilin shows preference to a closed form of syntaxin 1a like Munc18-1 (Torii et al., 2002), granuphilin and Munc18-1 must somehow be dissociated from syntaxin 1a to allow syntaxin 1a to form an open conformation and thus core-complex with other SNARE proteins. An inhibitory effect of overexpressed granuphilin on high $\mathrm{K}^{+}$-induced insulin secretion may be related to its ability to trap syntaxin $1 \mathrm{a}$ in a closed conformation. Future studies should focus on how the complex formation involving granuphilin, syntaxin 1a, and Munc181 is regulated.

\section{Melanophilin (exophilin3, Slac2-a)}

Melanophilin is a single protein that has been genetically proven to function as a Rab27a effector. The gene coding melanophilin has been discovered to be mutated in leaden coat-color mutant mice (Matesic et al., 2001). The leaden product was previously shown to function in the same pathway as Rab27a (ashen) and myosin Va (dilute), because all three mutations are suppressed by the cell autonomous, semidominant dilute suppressor, dsu (Moore et al., 1988). Because melanophilin shares a putative N-terminal Rab27a binding domain with granuphilin, it was predicted to be a Rab27a effector protein (Matesic et al., 2001). This proposition was proven to be correct by subsequent biochemical analyses showing that melanophilin directly and nucleotidedependently binds to Rab27a in vitro (Fukuda et al., 2002; Nagashima et al., 2002; Strom et al., 2002; Wu et al., 2002). Moreover, it directly binds to myosin Va through its C-terminal coiled-coil region-1 (Fukuda and Kuroda, 2002; Nagashima et al., 2002; Strom et al., 2002) (Fig. 1). The binding domain in myosin Va requires the presence of exon $\mathrm{F}$, an alternatively spliced exon expressed in melanocytes but not in neuroendocrine cells (Nagashima et al., 2002; Seperack et al., 1995; Wu et al., 2002). Genetic evidence and these biochemical studies suggest that melanophilin 


\section{Rab27a function}

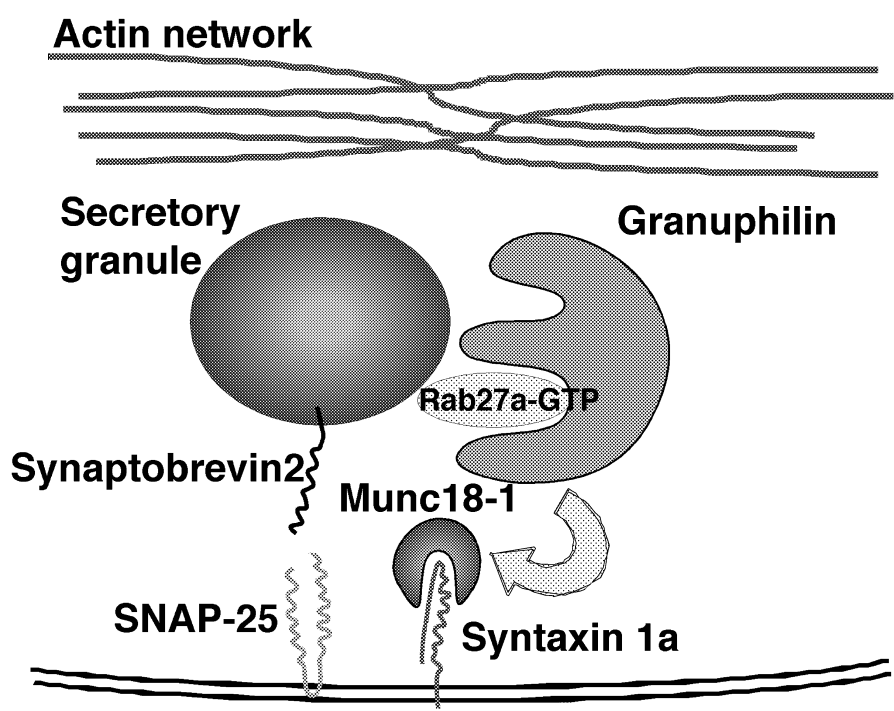

Plasma membrane



Actin network

Pancreatic beta cells

Melanocytes

Fig. 3. Modes of action of granuphilin and melanophilin. Rab27a is located on endocrine granules or lysosome-related organelles such as melanosomes, and is involved in various steps of the transport of these granule-like organelles. GTP-bound, active Rab27a forms a complex with organelle-specific effector proteins, such as granuphilin and melanophilin. Left, in pancreatic beta cells, granuphilin binds Rab27a on insulin granules and tether the granules to plasma membrane possibly through the interaction with syntaxin 1a and/or Munc18-1. Granuphilin complexes with syntaxin 1a and Munc18-1 may also regulate subsequent fusion events. Right, in melanocytes, melanophilin links Rab27a on melanosomes and myosin Va on actin filaments, and traps melanosomes in actin-rich peripheral areas to be ready for the transfer of melanosomes to adjacent keratinocytes.

links Rab27a on melanosomes and myosin Va on actin filaments (Fig. 3, right). Melanosomes are transported by fast, long-range, bi-directional, microtubule-dependent movements along the length of dendrites and by local movement on to actin filaments within distal regions of the dendrite (Wu et al., 1998). Without capture of melanosomes on actin networks through melanophilin, melanosomes are not retained in the periphery but are clustered near the perikaryotic regions, and thereby cannot be transferred to neighboring keratinocytes. The mode of melanophilin action is probably the clearest example of how Rab effector proteins act on a molecular level.

\section{Other putative effectors}

Other putative Rab27a effector proteins have not been characterized in detail and their physiological functions are unknown, although they are likely to regulate other secretory pathways in differentiated cells such as cytotoxic Tlymphocytes (Fig. 1).

(1) MyRIP (exophilin8, Slac2-c)

MyRIP was identified as a protein interacting with the tail of myosin VIIa from a retinal two-hybrid cDNA library (El-Amraoui et al., 2002). It directly binds to Rab27a by the $\mathrm{N}$-terminus and myosin VIIa through the middle region in vitro. MyRIP is localized on melanosomes in microvilli of retinal pigment epithelial cells that surround the tips of photoreceptor outer segments. It shows marked similarity to melanophilin in that it connects Rab27a and unconventional myosin in cells harboring melanosomes. MyRIP is expressed in a variety of tissues, including the synaptic area of retinal photoreceptor cells and inner ear hair cells, suggesting that it may be involved in the trafficking of other organelles, such as synaptic vesicles in specialized sensor cells.

\section{(2) JFC1 (exophilin 7, Slp1)}

JFC1 was identified by a yeast two-hybrid system as a protein that interacts with regulatory components of the NADPH oxidase, p67 phox (Berkowitz et al., 2001). Although it is abundantly expressed in leukocytes where the NADPH oxidase is restricted, it is widely expressed in other tissues. In vitro, JFC1 binds to Rab27a (Kuroda et al., 2002a), but it was not cofractionated with azurophil granules (Berkowitz et al., 2001), the lysosome-related organelles in neutrophils. 
Thus, the physiological function of JFC1 is unknown. The first $\mathrm{C} 2 \mathrm{~A}$ domain of the two tandem $\mathrm{C} 2$ domains, which is homologous to the $\mathrm{C} 2 \mathrm{~B}$ domain of synaptotagmin 1, possesses 3'-phosphoinositide binding activity. When this domain is expressed in cells, it shows the ability to bind to the plasma membrane in a $\mathrm{Ca}^{2+}$-inhibitory manner (Catz et al., 2002).

\section{(3) Others}

Other proteins that have a putative Rab27-binding domain are reported, including exophilin4-6 (Slp2, Slac2-b, Slp3) and Slp5 (Fukuda and Mikoshiba, 2001; Kuroda et al., 2002a; Kuroda et al., 2002b; Nagashima et al., 2002), although they remain poorly characterized except for the sequence information and the ability to bind Rab27a in vitro or when overexpressed in cell lines. It remains to be seen whether they actually represent Rab27 effectors.

\section{Rab27 vs. Rab3}

Members of the Rab3 subfamily (Rab3a, b, c, and d) have been proven to be specifically associated with various secretory vesicles (Jahn and Südhof, 1999; Takai et al., 2001). Overexpression of Rab3 proteins in various cell lines inhibits secretion in most cases, although Rabs are generally thought to positively promote vesicle transport. Rab3a, its regulators such as guanine nucleotide exchange factor and GTPase activating protein, and its effectors such as rabphilin3 and Rims, have been intensively characterized and are thought to be involved in the exocytosis of various secretory vesicles. Despite numerous studies, the function of Rab3 proteins has yet to be determined at the molecular level. One reason for this is that there is no clear phenotype in Rab3-knockout mice. For example, neither the size nor the refilling rate of the readily releasable pool was changed in Rab3a-deficient synapses. Instead, $\mathrm{Ca}^{2+}$-triggered fusion was increased, which resulted in an enhanced rundown of synaptic transmission (Geppert et al., 1997). These findings suggest that Rab3a is not involved in vesicle tethering, but rather plays an inhibitory role in vesicle fusion. Similarly, the only phenotype detected to date in Rab3d-deleted mice showed a slight enlargement of the granule size in exocrine cells (Riedel et al., 2002). The lack of clear phenotypes cannot be simply explained by functional complementation by coexisting Rab3 isoforms because the situation is similar even in cells that do not express other isoforms.

Compared with Rab3-knockout mice, ashen mice lacking functional Rab27a show clearer defects in the regulated secretory pathways, as described above. In the Rab family, the Rab27 subfamily has the closest sequence similarity to the Rab3 subfamily. In addition, Rab27 and Rab3 members are associated with exocytotic vesicles, suggesting that both function as exocytotic Rab proteins. This is consistent with the finding of a recent phylogenetic analysis that showed that Rab proteins with similar sequences show a similar pattern of cellular localization and/or function (Pereira-Leal and Seabra, 2001). It is noteworthy that Rab27 and Rab3 are often coexpressed in secretory cells such as neurons (Rab3a, Rab3c, and Rab27b) (Fischer von Mollard et al., 1994; our unpublished observations), pancreatic beta cells (Rab3a-d, Rab27a) (Regazzi et al., 1996; Yi et al., 2002), and melanocytes (Rab3a and Rab27a) (Araki et al., 2000; Bahadoran et al., 2001; Hume et al., 2001). Interestingly, overexpression of each Rab27a and Rab3a protein in the same pancreatic beta cell line produces opposite effects on insulin secretion (Yi et al., 2002). Thus, Rab3 and Rab27 may have different functions on the same secretory vesicles.

\section{Future directions}

Based on the findings described above, it is very likely that Rab27 regulates various exocytotic mechanisms using multiple organelle-specific effectors. Although the precise physiological roles of these putative effectors will soon be investigated in detail in differentiated cells (cell lines) or in whole mice, several important questions remain to be clarified.

First, regulators such as guanine nucleotide exchange factor, GTPase activating protein, and guanine nucleotide dissociation inhibitor are completely unknown for Rab27. Rab27a is tightly associated with the granule membrane and is merely observed in the cytosol (Yi et al., 2002). Moreover, the predicted dominant-negative forms (T23N, N133I) are unstable in both transfected cell lines (Yi et al., 2002) and transgenic mice (Ramalho et al., 2002), whereas wildtype Rab27a is able to bind effector proteins as well as the active form (Q78L) (Yi et al., 2002). These observations suggest that the regulators for Rab27a are both unique and specific. Note that Rab27a is specifically sensitive in defects that generally affect prenylation and membrane association of Rab proteins, such as choroideremia caused by mutations in the Rab escort protein-1 gene (Seabra et al., 1995 ) or the gunmetal mouse that has a mutation in the Rab geranylgeranyl transferase $\alpha$ gene (Detter et al., 2000).

Second, the tissue distributions of exophilin family proteins are relatively broad, except for granuphilin. Although melanophilin is significantly expressed in most adult tissues (Matesic et al., 2001; our unpublished observations), specific cells may exist in a selected tissue; for example, melanophilin is hardly detected in whole skin but is highly expressed in melanocytes. The role of melanophilin in other tissues devoid of melanosomes is unknown. It has been shown that lytic granules kill target cells normally in leaden cytotoxic T-lymphocytes (Hume et al., 2002). By contrast, granuphilin has a very restricted tissue distribution: it is specifically expressed in pancreatic beta cells, but not in alpha cells that are located in the same pancreatic islets (Wang et al., 1999). Neighboring endocrine cells seem to employ different Rab effectors and distinct mechanisms.

Third, different putative Rab27 effectors are expressed in the same cells and show at least partially distinct distribu- 
tions. For instance, melanophilin and exophilin4/Slp1 are coexpressed in melanocytes (Kuroda et al., 2002a; our unpublished observations). Yet it is unknown just how these effectors discriminately bind Rab27a in distinct membrane compartments and differentially function in the same cells.

Fourth, some Rab27 effectors show affinities to other Rab proteins that belong to different subfamilies, at least in vitro (Kuroda et al., 2002a; Yi et al., 2002). It is not known whether these effector proteins can change their Rab partners in different steps of vesicle transport.

Recent advances in molecular genetics and genome identification have helped to uncover the molecular nature of genetic diseases and to identify the family of proteins that have similar primary sequences. In the field of Rab27 research, these two approaches have converged to yield promising results and continue to stimulate fruitful research. Future research should emphasize a rapid expansion of our understanding of the physiology and pathology of minor secretory vesicles differentiated in multicellular organisms, which have thus far been poorly characterized relative to that of synaptic vesicles in neurons.

Acknowledgments. We would like to thank Dr. H. Ohno (Kanazawa University) for giving us an opportunity to write this review article. We also would like to thank Dr. T. Takeuchi (Gunma University) for his generous support. This work was supported by a Grant-in-Aid for Scientific Research on Priority Areas from the Ministry of Education, Culture, Sports, Science and Technology of Japan, and in part by grants from Takeda Science Foundation, The Naito Foundation, and Japan Insulin Study Group Award (to T.I.).

\section{References}

Araki, K., Horikawa, T., Chakraborty, A.K., Nakagawa, K., Itoh, H., Oka, M., Funasaka, Y., Pawelek, J., and Ichihashi, M. 2000. Small GTPase Rab3A is associated with melanosomes in melanoma cells. Pigment Cell Res., 13: 332-336.

Bahadoran, P., Aberdam, E., Mantoux, F., Buscà, R., Bille, K., Yalman, N., de Sainte-Basile, G., Casaroli-Marano, R., Ortonne, J.-P., and Ballotti, R. 2001. Rab27a: a key to melanosome transport in human melanocytes. J. Cell Biol., 152: 843-849.

Barral, D.C., Ramalho, J.S., Anders, R., Hume, A.N., Knapton, H.J., Tolmachova, T., Collinson, L.M., Goulding, D., Authi, K.S., and Seabra, M.C. 2002. Functional redundancy of Rab27 proteins and the pathogenesis of Griscelli syndrome. J. Clin. Invest., 110: 247-257.

Berkowitz, J.K.M., Catz, S.D., Johnson, J.L., Ruedi, J.M., Thon, V., and Babior, B.M. 2001. JFC1, a novel tandem $\mathrm{C} 2$ domain-containing protein associated with the leukocyte NADPH oxidase. J. Biol. Chem., 276: 18855-18862.

Blott, E.J. and Griffiths, G.M. 2002. Secretory lysosomes. Nat. Rev. Mol. Cell Biol., 3: 122-131.

Bock, J.B., Matern, H.T., Peden, A.A., and Scheller, R.H. 2001. A genomic perspective on membrane compartment organization. Nature, 409: 839-841.

Burgess, T.L. and Kelly, R.B. 1987. Constitutive and regulated secretion of proteins. Annu. Rev. Cell Biol., 3: 243-293.

Castillo, P.E., Janz, R., Südhof, T.C., Tzounopoulos, T., Malenka, R.C., and Nicoll, R.A. 1997. Rab3A is essential for mossy fibre long-term potentiation in the hippocampus. Nature, 388: 590-593.
Catz, S.D., Johnson, J.L., and Babior, B.M. 2002. The C2A domain of JFC1 binds to 3'-phosphorylated phosphoinositides and directs plasma membrane association in living cells. Proc. Natl. Acad. Sci., USA, 99: 11652-11657.

Chow, R.H., von Rüden, L., and Neher, E. 1992. Delay in vesicle fusion revealed by electrochemical monitoring of single secretory events in adrenal chromaffin cells. Nature, 356: 60-63.

Coppola, T., Frantz, C., Perret-Menoud, V., Gattesco, S., Hirling, H., and Regazzi, R. 2002. Prancreatic $\beta$-cell protein granuphilin binds Rab3 and Munc-18 and controls exocytosis. Mol. Biol. Cell, 13: 1906-1915.

Dell'Angelica, E.C., Mullins, C., Caplan, S., and Bonifacino, J.S. 2000. Lysosome-related organelles. FASEB J., 14: 1265-1278.

Detter, J.C., Zhang, Q., Mules, E.H., Novak, E.K., Mishra, V.S., Li, W., McMurtrie, E.B., Tchernev, V.T., Wallace, M.R., Seabra, M.C., Swank, R.T., and Kingsmore, S.F. 2000. Rab geranylgeranyl transferase $\alpha$ mutation in the gunmetal mouse reduces Rab prenylation and platelet synthesis. Proc. Natl. Acad. Sci. USA, 97: 4144-4149.

Dulubova, I., Sugita, S., Hill, S., Hosaka, M., Fernandez, I., Südhof, T.C., and Rizo, J. 1999. A conformational switch in syntaxin during exocytosis: role for munc18. EMBO J., 16: 4372-4382.

Eggenschwiler, J.T., Espinoza, E., and Anderson, K.V. 2001. Rab23 is an essential negative regulator of the mouse Sonic hedgehog signalling pathway. Nature, 412: 194-198.

El-Amraoui, A., Schonn, J.-S., Küssel-Andermann, P., Blanchard, S., Desnoe, C., Henry. J.-P., Wolfrum, U., Darchen, F., and Petit, C. 2002. MyRIP, a novel Rab effector, enables myosin VIIa recruitment to retinal melanosomes. EMBO Rep., 3: 463-470.

Fischer von Mollard, G., Stahl, B., Khokhlatchev, A., Südhof, T.C., and Jahn, R. 1994. Rab3C is a synaptic vesicle protein that dissociates from synaptic vesicles after stimulation of exocytosis. J. Biol. Chem., 269: 10971-10974.

Fukuda, M. 2002. Synaptotagmin-like protein (Slp) homology domain 1 of Slac2-a/melanophilin is a critical determinant of GTP-dependent specific binding to Rab27A. J. Biol. Chem., 277: 40118-40124.

Fukuda, M. and Kuroda, T.S. 2002. Slac2-c (Synaptotagmin-like protein homologue lacking $\underline{\mathrm{C} 2}$ domains-c), a novel linker protein that interacts with Rab27, myosin Va/VIIa, and actin. J. Biol. Chem., 277: 4309643103.

Fukuda, M., Kuroda, T.S., and Mikoshiba, K. 2002. Slac2-a/melanophilin, the missing link between Rab27 and myosin Va: implication of a tripartite protein complex for melanosome transport. J. Biol. Chem., 277: 12432-12436.

Fukuda, M. and Mikoshiba, K. 2001. Synaptotagmin-like protein 1-3: a novel family of C-terminal-type tandem C2 proteins. Biochem. Biophys. Res. Commun., 281: 1226-1233.

Garner, C.C., Kindler, S., and Gundelfinger, E.D. 2000. Molecular determinants of presynaptic active zones. Curr. Opin. Neurobiol., 10: $321-$ 327.

Geppert, M., Bolshakov, V.Y., Siegelbaum, S.A., Takei, K., De Camilli, P., Hammer, R.E., and Südhof, T.C. 1994. The role of Rab3A in neurotransmitter release. Nature, 369: 493-497.

Geppert, M., Goda, Y., Stevens, C.F., and Südhof, T.C. 1997. The small GTP-binding protein Rab3A regulates a late step in synaptic vesicle fusion. Nature, 387: 810-814.

Haddad, E.K., Wu, X., Hammer III, J.A., and Henkart, P.A. 2001. Defective granule exocytosis in Rab27a-deficient lymphocytes from ashen mice. J. Cell Biol., 152: 835-841.

Hata, Y., Slaughter, C.A., and Südhof, C. 1993. Synaptic vesicle fusion complex contains unc-18 homologue bound to syntaxin. Nature, $\mathbf{3 6 6}$ : $347-351$.

Hume, A.N., Collinson, L.M., Hopkins, C.R., Strom, M., Barral, D.C., Bossi, G., Griffiths, G.M., and Seabra, M.C. 2002. The leaden gene product is required with Rab27a to recruit myosin Va to melanosomes in 
melanocytes. Traffic, 3: 193-202.

Hume, A.N., Collinson, L.M., Rapak, A., Gomes, A.Q., Hopkins, C.R., and Seabra, M.C. 2001. Rab27a regulates the peripheral distribution of melanosomes in melanocytes. J. Cell Biol., 152: 795-808.

Jahn, R. and Südhof, T.C. 1999. Membrane fusion and exocytosis. Annu. Rev. Biochem., 68: 863-911.

Kapfhamer, D., Valladares, O., Sun, Y., Nolan, P.M., Rux, J.J., Arnold, S.E., Veasey, S.C., and Bućan, M. 2002. Mutations in Rab3a alter circadian period and homeostatic response to sleep loss in the mouse. Nat. Genet., 32: 290-295.

Kleine, C., Philippe, N., Le Deist, F., Fraitag, S., Prost, C., Durandy, A., Fischer, A., and Griscelli, C. 1994. Partial albinism with immunodeficiency (Griscelli syndrome). J. Pediatr., 125: 886-895.

Kuroda, T.S., Fukuda, M., Ariga, H., and Mikoshiba, K. 2002a. The Slp homology domain of synaptotagmin-like proteins 1-4 and Slac2 functions as a novel Rab27A binding domain. J. Biol. Chem., 277: 92129218

Kuroda, T.S., Fukuda, M., Ariga, H., and Mikoshiba, K. 2002 b. Synaptotagmin-like protein 5: a novel Rab27a effector with C-terminal tandem C2 domains. Biochem. Biophys. Res. Commun., 293: 899-906.

Loftus, S.K., Larson, D.M., Baxter, L.L., Antonellis, A., Chen, Y., Wu, X., Jiang, Y., Bittner, M., Hammer III, J.A., and Paven, W.J. 2002. Mutation of melanosome protein Rab38 in chocolate mice. Proc. Natl. Acad. Sci. USA, 99: 4471-4476.

Lonart, G., Janz, R., Johnson, K.M., and Südhof, T.C. 1998. Mechanism of action of rab3A in mossy fiber LTP. Neuron, 21: 1141-1150.

Marks, M.S. and Seabra, M.C. 2001. The melanosome: membrane dynamics in black and white. Nat. Rev. Mol. Cell Biol., 2: 1-11.

Matesic, L.E., Yip, R., Reuss, A.E., Swing, D.A., O’Sullivan, T.N., Fletcher, C.F., Copeland, N.G., and Jenkins, N.A. 2001. Mutations in $M l p h$, encoding a member of the Rab effector family, cause the melanosome transport defects observed in leaden mice. Proc. Natl. Acad. Sci. USA, 98: 10238-10243.

Ménasché, G., Pastural, E., Feldmann, J., Certain, S., Ersoy, F., Dupuis, S., Wulffraat, N., Bianchi, D., Fischer, A., Le Deist, F., and de Saint Basile, G. 2000. Mutations in RAB27A cause Griscelli syndrome associated with haemophagocytic syndrome. Nat. Genet., 25: 173-176.

Moore, K.J., Swing, D.A., Rinchik, E.M., Mucenski, M.L., Buchberg, A.M., Copeland, N.G., and Jenkins, N.A. 1988. The murine dilute suppressor gene $d s u$ suppresses the coat-color phenotype of three pigment mutations that alter melanocyte morphology, $d$, ash and In. Genetics, 119: 933-941.

Nagashima, K., Torii, S., Yi, Z., Igarashi, M., Okamoto, K., Takeuchi, T., and Izumi, T. 2002. Melanophilin directly links Rab27a and myosin Va through its distinct coiled-coil regions. FEBS Lett., 517: 233-238.

Novak, E.K., Gautam, R., Reddington, M., Collinson, L.M., Copeland, N.G., Jenkins, N.A., McGarry, M.P., and Swank, R.T. 2002. The regulation of platelet-dense granules by Rab27a in the ashen mouse, a model of Hermansky-Pudlak and Griscelli syndromes, is granule-specific and dependent on genetic background. Blood, 100: 128-135.

Ostermeier, C. and Brunger, A.T. 1999. Structural basis of Rab effector specificity: crystal structure of the small G protein Rab3A complexed with the effector domain of rabphilin-3A. Cell, 96: 363-374.

Pereira-Leal, J.B. and Seabra, M.C. 2001. Evolution of the Rab family of small GTP-binding proteins. J. Mol. Biol., 313: 889-901.

Ramalho, J.S., Anders, R., Jaissle, G.B., Seeliger, M.W., Huxley, C., and Seabra, M.C. 2002. Rapid degradation of dominant-negative Rab27 proteins in vivo precludes their use in transgenic mouse models. $B M C$ Cell Biol., 3: 26.

Regazzi, R., Ravazzola, M., Iezzi, M., Lang, J., Zahraoui, A., Andereggen, E., Morel, P., Takai, Y., and Wollheim, C.B. 1996. Expression, localization and functional role of small GTPases of the Rab3 family in insulin-secreting cells. J. Cell Sci., 109: 2265-2273.
Riedel, D., Antonin, W., Fernandez-Chacon, R., de Toledo, G..A., Jo, T., Geppert, M., Valentijin, J.A., Valentijin, K., Jamieson, J.D., Südhof, T.C., and Jahn, R. 2002. Rab3D is not required for exocrine exocytosis but for maintenance of normally sized secretory granules. Mol. Cell Biol., 22: 6487-6497.

Rizo, J. and Südhof, T.C. 1998. C $_{2}$-domains, structure and function of a universal $\mathrm{Ca}^{2+}$-binding domain. J. Biol. Chem., 273: 15879-15882.

Rizo, J. and Südhof, T.C. 2002. SNAREs and Munc18 in synaptic vesicle fusion. Nat. Rev. Neurosci., 3: 641-653.

Sabatini, B. and Regehr, W.G. 1996. Timing of neurotransmission at fast synapses in the mammalian brain. Nature, 384: 170-172.

Seabra, M.C., Ho, Y.K., and Anant, J.S. 1995. Deficient geranylgeranylation of Ram/Rab27 in choroideremia. J. Biol. Chem., 270: 24220-24227.

Segev, N. 2001. Ypt and Rab GTPases: insight into functions through novel interactions. Curr. Opin. Cell Biol., 13: 500-511.

Seperack, P.K., Mercer, J.A., Strobel, M.C., Copelamd, N.G., and Jenkins, N.A. 1995. Retroviral sequences located within an intron of the dilute gene alter dilute expression in a tissue-specific manner. EMBO J., 14: 2326-2332.

Shirataki, H., Kaibuchi, K., Sakota, T., Kishida, S., Yamaguchi, T., Wada, K., Miyazaki, M., and Takai, Y. 1993. Rabphilin-3A, a putative target protein for smg p25A/rab3A p25 small GTP-binding protein related to synaptotagmin. Mol. Cell Biol., 13: 2061-2068.

Stinchcombe, J.C., Barral, D.C., Mules, E.H., Booth, S., Hume, A.N., Machesky, L.M., Seabra, M.C., and Griffiths, G.M. 2001. Rab27a is required for regulated secretion in cytotoxic T lymphocytes. J. Cell Biol., 152: 825-833.

Strom, M., Hume, A.N., Tarafder, A.K., Barkagianni, E., and Seabra, M.C. 2002. A family of Rab27-binding proteins: melanophilin links Rab27a and myosin Va function in melanosome transport. J. Biol. Chem., 277: 25423-25430.

Südhof, T.C. 1995. The synaptic vesicle cycle: a cascade of protein-protein interactions. Nature, 375: 645-653.

Takai, Y., Sasaki, T., and Matozaki, T. 2001. Small GTP-binding proteins. Physiol. Rev., 81: 153-208.

Torii, S., Zhao, S., Yi, Z., Takeuchi, T., and Izumi, T. 2002. Granuphilin modulates the exocytosis of secretory granules through interaction with syntaxin 1a. Mol. Cell Biol., 22: 5518-5526.

Verhoeven, K., De Jonghe, P., Coen, K., Verpoorten, N., Auer-Grumbach, M., Kwon, J.M., FitzPatrick, D., Schmedding, E., De Vriendt, E., Jacobs, A., Van Gerwen, V., Wagner, K., Hartung, H.-P., and Timmerman, V. 2003. Mutations in the small GTP-ase late endosomal protein RAB7 cause Charcot-Marie-Tooth type 2B neuropathy. Am. J. Hum. Genet., 72: 722-727.

Wang, J., Takeuchi, T., Yokota, H., and Izumi, T. 1999. Novel rabphilin3-like protein associates with insulin-containing granules in pancreatic beta cells. J. Biol. Chem., 274: 28542-28548.

Wang, X., Hu, B., Zimmermann, B., and Kilimann, M.W. 2001. Rim1 and rabphilin-3 bind Rab3-GTP by composite determinants partially related through N-terminal $\alpha$-helix motifs. J. Biol. Chem., 276: 32480-32488.

Wilson, S.M., Yip, R., Swing, D.A., O’Sullivan, T.N., Zhang, Y., Novak, E.K., Swank, R.T., Russell, L.B., Copeland, N.G., and Jenkins, N.A. 2000. A mutation in Rab27a causes the vesicle transport defects observed in ashen mice. Proc. Natl. Acad. Sci. USA, 97: 7933-7938.

Wu, X., Bowers, B., Rao, K., Wei, Q., and Hammer III, J.A. 1998. Visualization of melanosome dynamics within wild-type and dilute melanocytes suggest a paradigm for myosin $\mathrm{V}$ function in vivo. J. Cell Biol., 143: 1899-1918.

Wu, X.S., Rao, K., Zhang, H., Wang, F., Sellers, J.R., Matesic, L.E., Copelamd, N.G., Jenkins, N.A., and Hammer III, J.A. 2002. Identification of an organelle receptor for myosin-Va. Nat. Cell Biol., 4: 271-278. Yaekura, K., Julyan, R., Wicksteed, B.L., Hays, L.B., Alarcon, C., Sommers, S., Poitout, V., Baskin, D.G., Wang, Y., Philipson, L.H., and 
Rhodes, C.J. 2003. Insulin secretory deficiency and glucose intolerance in Rab3A null mice. J. Biol. Chem., 278: 9715-9721.

Yi, Z., Yokota, H., Torii, S., Aoki, T., Hosaka, M., Zhao, S., Takata, K., Takeuchi, T., and Izumi, T. 2002. The Rab27a/granuphilin complex regulates the exocytosis of insulin-containing dense-core granules. Mol. Cell Biol., 22: 1858-1867.

Zerial, M. and McBride, H. 2001. Rab proteins as membrane organizers.
Nat. Rev. Mol. Cell Biol., 2: 107-118.

Zhao, S., Torii, S., Yokota-Hashimoto, H., Takeuchi, T., and Izumi, T. 2002. Involvement of Rab27b in the regulated secretion of pituitary hormones. Endocrinol., 143: 1817-1824.

(Received for publication, September 5, 2003

and accepted, October 4, 2003) 